\title{
EPIPHYTIC AND ENDOPHYTIC PHYLLOSPHERE MICROFLORA OF CASSYTHA FILIFORMIS L. AND ITS HOSTS
}

\author{
Irum Mukhtar*, Sobia Mushtaq, Amna Ali and Ibatsam Khokhar \\ Institute of Plant Pathology, University of the Punjab, Lahore, Pakistan \\ *E-mail: erumm21@yahoo.com
}

\begin{abstract}
In the present study, samples of Cassytha filiformis L. and healthy leaves of two of its host plants viz. Bougainvillea spectabilis Willd (Nyctaginaceae) and Citrus aurantifolia Swingle (Rutaceae) were collected simultaneously from different areas of Lahore, Pakistan. To analyze epiphytic microflora, washings of host leaf/parasite stem were used for the isolation. For endophytic microbes, sterilized homogenized host leaf/parasite stem tissue mixture was plated separately on $2 \%$ MEA and LB media for bacterial and fungal isolation. Each fungal colony was purified and identified after 6-8 days on the basis of morphological characteristics. Bacterial strains were identified including pigment, colony form, elevation, margin, texture and opacity. In addition, bacterial strains were tested with respect to gram reaction and biochemical characteristics. The total colonization frequency of the endophytes was maximum for $B$. spectabilis suggesting that this plant tissue harbored more endophytic bacteria than $C$. aurantifolia. On the other hand Cassytha filiformis stem, parasitizing B. spectabilis and $C$. aurantifolia supported a total of 4 bacterial species as endophytes but different to its host plants. Therefore, Sørensen's quotient of similarity (QS) for the endophytic and epiphytic bacterial assemblages was zero. Overall, the endophyte and epiphyte assemblage of hosts and their parasite showed no overlap.
\end{abstract}

Key words: Microflora, host, parasite, endophytes, epiphytes, phyllosphere.

\section{INTRODUCTION}

The aerial parts of plants including leaves, stems, buds, flowers and fruits provide a habitat for microorganisms termed the phyllosphere. Microbes can be found both as epiphytes on the plant surface and as endophytes within plant tissues (Arnold et al. 2000, Inacio et al. 2002, Lindow and Brandl 2003, Yadav et al. 2004, 2005, Stapleton and Simmons 2006). Bacteria are considered to be the dominant microbial inhabitants of the phyllosphere, although archaea, filamentous fungi, and yeasts may also be important. Phyllosphere bacteria can promote plant growth and both suppress and stimulate the colonisation and infection of tissues by plant pathogens (Lindow and Brandl 2003, Rasche et al. 2006). Similarly, fungal endophytes of leaves may deter herbivores, protect against pathogens and increase drought tolerance (Arnold et al. 2003, Schweitzer et al. 2006).

A few tropical plants including palms (Southcott and Johnson 1997, Rodrigues 1994), banana (Brown et al. 1998) and mangroves (Suryanarayanan et al. 1998) have also been 
studied for the presence of endophytes in case of attack of parasitic plant. However, Petrini et al. (1992) studied host and parasite endophytes altogether. On the other hand, there appears to be no comparative study on endophytes and epiphytes of an angiosperm host and its angiosperm parasite. The study of a host-parasite microflora is expected to throw some light on host specificity of endophytes and epiphytes. Phyllospheric study can also be helpful to find out some relation between parasite plants and their hosts. Hence, we studied Cassytha filiformis, an angiosperm parasite and two of its angiosperm hosts belonging to different families for their endophyte and epiphyte microbial assemblages.

\section{MATERIALS AND METHODS}

Sample collection: In the present study, stem samples of C. filiformis were collected from its two host plants viz. Bougainvillea spectabilis Willd (Nyctaginaceae) and Citrus aurantifolia Swingle (Rutaceae). Stem portion of the parasite that was not in contact with the host stem were sampled. Healthy leaves of parasitized host plants were also collected. Host leaves and C. filiformis stem samples were collected simultaneously from different areas of Lahore, Pakistan. The host and the parasite samples were put separately into sterile bags then taken back to laboratory in less than $2 \mathrm{~h}$ for isolation of epiphytic and endophytic phyllospheric microorganisms.

Microbial isolation and identification: To analyze epiphytic microflora of host and parasite, washings of host leaf and parasite stem were used for microbial isolation. Each host leaf and related parasite stem samples were washed separately by shaking for one hour with $100 \mathrm{ml}$ of sterile distilled water. An aliquot of $1 \mathrm{ml}$ from host leaf and parasite stem wash were plated separately on $2 \%$ Malt Extract Agar (MEA) medium: Malt 20 g/L, agar $20 \mathrm{~g} / \mathrm{L}$ for fungal isolation and LB medium: Peptone $5 \mathrm{~g} / \mathrm{L}$, Beef Extract $3 \mathrm{~g} / \mathrm{L}$, Agar $15 \mathrm{~g} / \mathrm{L}$ for bacterial isolation.

For endophytic microbial isolations, host leaf and parasite stem were submerged separately in $70 \%$ ethanol $(\mathrm{v} / \mathrm{v})$ for $1 \mathrm{~min}$ to wet the surface, followed by surface disinfection for $3 \mathrm{~min}$ in $2 \%$ $\mathrm{NaClO}_{2}$. Afterward sample materials were rinsed 2-3 times with sterile distilled water, transferred to sterile filter paper and dried in laminar flow. About $2 \mathrm{~g}$ of sterilized sample (host leaf/parasite stem) were ground into paste with $20 \mathrm{~mL}$ of sterilized water. For fungal isolation $1 \mathrm{~mL}$ of paste solution was added on the MEA medium into a Petri plate and cultured at $25 \pm 2{ }^{\circ} \mathrm{C}$. For bacterial isolation, 1 $\mathrm{mL}$ of paste solution was added on the LB medium and incubated at $37^{\circ} \mathrm{C}$. Fungal colonies were counted after 3-4 days. Each fungal colony was purified and identified after 6-8 days on the basis of morphological characteristics (Domsch et al. 1980, Ellis 1971 and 1976). Bacterial strains were identified including pigment, colony form, elevation, margin, texture and opacity (Smibert and Krieg 1981). In addition, bacterial strains were tested with respect to Gram reaction and biochemical characteristics (Holt et al. 1994). Fungi and bacteria were isolated with the surface sterilization method, regarded as inhabitants of the leaf interior of host and parasite, whereas those isolated only with the washing method are regarded as inhabitants of the leaf surface of host and parasite (Osono and Mori 2004, 2005).

Sørensen's quotient of similarity $(Q S)$ was calculated to examine the similarity of microflora assemblages in host leaf interiors and on leaf surfaces as well as in parasite.

$$
Q S=2 \mathrm{a} /(2 \mathrm{a}+\mathrm{b}+\mathrm{c})
$$

Where $a$ is the number of common species and $b$ and $c$ are the numbers of species specific to the interior and the surface, respectively. Frequency of 
individual species was calculated as the numbers of colonies of the species grown divided by the total number of all colonies isolated from each sample, expressed as percentage.

\section{RESULTS}

Diversity of Bacteria in Host and Parasite Phyllosphere: The leaf of Citrus aurantifolia anchoraged two bacterial species as endophytes, while Bougainvillea spectabilis had three bacterial strains as endophytes (Table 1). The total colonization frequency of the endophyte was maximum for $B$. spectabilis suggesting that this plant tissue harboured more endophytic bacteria than $C$. aurantifolia (Table 1). On the other hand C. filiformis stem, parasitizing B. spectabilis and C. aurantifolia supported a total of four bacterial species as endophytes but different to its host plants. Therefore Sørensen's $Q S$ for the endophytic and epiphytic bacterial assemblages was zero (Table 2). Similar observations were recorded in case of epiphytic bacterial species for host plants and parasite. These results strongly suggest the existence of host specificity as well as habitat, among endophytic and epiphytic bacterial species (Tables 1 and 2).

Bougainvillea spectabilis leaves had no fungal species as endophytes (Table 1). Although, some epiphytic fungi were isolated from phyllospere of B. spectabilis (Table 2). On the other hand, $C$. aurantifolia showed support in case of both epi and endophytic fungi. The total colonization frequency of fungi was maximum for $C$. aurantifolia suggesting that this plant tissue harboured more fungi (Table 1). Aspergillus nidulans var. dentatus was the only fungal species found in epiphytic and endophytic phyllosphere of C. aurantifolia. Alternatively, C. filiformis stem, parasitizing $B$. spectabilis and $C$. aurantifolia supported a total of five fungal species as epiphytic fungal flora. Sørensen's $Q S$ for the endophytic and epiphytic assemblages was zero between $C$. filiformis and B. spectabilis. Similarity of fungi was also found zero between $C$. filiformis and $C$. aurantifolia (Table 2).

\section{DISCUSSION}

The microbial communities of the phyllosphere are diverse, supporting numerous genera of bacteria, filamentous fungi, yeasts, algae and in some situations protozoans and nematodes (Morris and Kinkel 2002, Lindow and Brandl 2003). Bacteria are the most numerous and diverse colonists of leaves, with culturable counts ranging between $10^{2}$ to $10^{12}$ cells/g leaf (Thompson et al. 1993, Inacio et al. 2002). In the present study distinct bacterial and fungal species were isolated as endophytes and epiphytes of $C$. filiformis and its two host plants. The plant body of $C$. filiformis is represented by a leafless, yellow green stem that tightly coils around the stem of its host. It also produces haustoria that penetrate the host stem tissue and facilitate the absorption of nutrients from the host. Thus, the parasite is in close contact with its host and consequently, it is exposed virtually to the same type and load of microbes. But in present study host-parasite combination is zero for endophytic assemblages. These results strongly suggest the existence of some degree of host specificity as well as habitat conditions. Plant species, leaf age, leaf position, physical environmental condition, and availability of immigrant inoculum have also been suggested to be involved in determining species of microbes in the phyllosphere (Andrews et al. 1980, O'Brien and Lindow 1989, Wilson and Lindow 1994). Leaf surface topography and nutrients present on the leaf surface are generally recognized as important regulators of phyllosphere microbial communities, little research has been done at the whole community level (Hirano and Upper 2000, Yadav et al. 2005, Yadav et al. 2008). 
Table 1. Colonization Frequency of endophytes and epiphytes in host plants.

\begin{tabular}{|c|c|c|c|c|c|c|c|}
\hline \multirow[t]{2}{*}{ HOST PLANTS } & \multicolumn{3}{|c|}{ EPIPHYTIC SPECIES } & \multicolumn{4}{|c|}{$\begin{array}{l}\text { ENDOPHYTIC SPECIES } \\
\end{array}$} \\
\hline & $\begin{array}{l}\text { Bacterial } \\
\text { species }\end{array}$ & $\begin{array}{l}\text { Colony } \\
\text { Frequency }\end{array}$ & $\begin{array}{c}\text { Colony } \\
\%\end{array}$ & Bacterial species & $\begin{array}{l}\text { Colony } \\
\text { Frequency }\end{array}$ & $\begin{array}{c}\text { Colony } \\
\%\end{array}$ & QS \\
\hline \multirow[t]{2}{*}{ Citrus aurantifolia } & $\begin{array}{l}\text { Enterobacter } \\
\text { agglomerans }\end{array}$ & 2 & 9.52 & $\begin{array}{l}\text { Micrococcus } \\
\text { luteus }\end{array}$ & 3 & 14.2 & 0.0 \\
\hline & & & & Proteus vulgaris & 4 & 14.28 & \\
\hline \multirow[t]{3}{*}{$\begin{array}{c}\text { Bougainvillea } \\
\text { spectabilis }\end{array}$} & $\begin{array}{c}\text { Acetobacter } \\
\text { aceti }\end{array}$ & 4 & 13.3 & $\begin{array}{l}\text { Bordetella } \\
\quad \text { pertussis }\end{array}$ & 3 & 10 & 0.0 \\
\hline & $\begin{array}{l}\text { Acidovorax } \\
\text { temperans }\end{array}$ & 5 & 16.6 & Ensifer adhaerens & 2 & 6.06 & \\
\hline & & & & $\begin{array}{l}\text { Enterobacter } \\
\text { agglomerans }\end{array}$ & 3 & 10 & \\
\hline \multirow[t]{8}{*}{ Citrus aurantifolia } & Fungal species & $\begin{array}{c}\text { Colony } \\
\text { Frequency }\end{array}$ & $\begin{array}{c}\text { Colony } \\
\%\end{array}$ & Fungal species & $\begin{array}{c}\text { Colony } \\
\text { Frequency }\end{array}$ & $\begin{array}{c}\text { Colony } \\
\%\end{array}$ & QS \\
\hline & $\begin{array}{l}\text { Alternaria } \\
\text { alternata }\end{array}$ & 2 & 11 & Aspergillus reperi & 9 & 50 & 0.1 \\
\hline & Alternaria sp. & 2 & 11 & Aspergillus flavus & 2 & 11 & \\
\hline & $\begin{array}{l}\text { Aaspergillus } \\
\text { fumigatus }\end{array}$ & 2 & 11 & $\begin{array}{l}\text { Alternaria } \\
\quad \text { alternata }\end{array}$ & 1 & 5 & \\
\hline & $\begin{array}{l}\text { Aspergillus } \\
\text { flavus }\end{array}$ & 2 & 11 & $\begin{array}{l}\text { Aspergillus } \\
\quad \text { nidulans var. } \\
\text { dentatus }\end{array}$ & 6 & 33 & \\
\hline & $\begin{array}{l}\text { Aspergillus } \\
\quad \text { nidulans var. } \\
\text { dentatus }\end{array}$ & 3 & 17 & & & & \\
\hline & $\begin{array}{l}\text { Aspergillus } \\
\text { phoenicis }\end{array}$ & 1 & 5 & & & & \\
\hline & $\begin{array}{l}\text { Curvularia } \\
\text { ovoidea }\end{array}$ & 5 & 29 & & & & \\
\hline \multirow[t]{3}{*}{$\begin{array}{c}\text { Bougainvillea } \\
\text { spectabilis }\end{array}$} & $\begin{array}{l}\text { Aspergillus } \\
\text { avenaceus }\end{array}$ & 1 & 20 & & 0 & 0 & 0.0 \\
\hline & $\begin{array}{l}\text { Aspergilllus } \\
\text { fumigatus }\end{array}$ & 3 & 60 & & 0 & 0 & \\
\hline & $\begin{array}{l}\text { Curvularia } \\
\text { clavata }\end{array}$ & 1 & 20 & & & & \\
\hline
\end{tabular}

Table 2. Colonization frequency of endophytes and epiphytes in Cassytha filiformis parasitizing different hosts.

\begin{tabular}{|c|c|c|c|c|c|c|c|}
\hline \multirow[t]{2}{*}{ PARASITIC PLANT } & \multicolumn{3}{|c|}{ EPIPHYTIC SPECIES } & \multicolumn{4}{|c|}{ ENDOPHYTIC SPECIES } \\
\hline & $\begin{array}{c}\text { Bacterial } \\
\text { species }\end{array}$ & $\begin{array}{c}\text { Colony } \\
\text { Frequency }\end{array}$ & $\begin{array}{c}\text { Colony } \\
\%\end{array}$ & Bacterial species & $\begin{array}{c}\text { Colony } \\
\text { Frequency }\end{array}$ & $\begin{array}{c}\text { Colony } \\
\%\end{array}$ & QS \\
\hline $\begin{array}{l}\text { Cassytha filiformis } \\
\text { parasitizing on }\end{array}$ & $\begin{array}{r}\text { Pediococcus } \\
\text { damnosus }\end{array}$ & 2 & 9.52 & $\begin{array}{l}\text { Stenotrophomonas } \\
\text { maltophilia }\end{array}$ & 3 & 14.2 & 0.0 \\
\hline Citrus aurantifolia & $\begin{array}{l}\text { Microbacterium } \\
\text { lacticum }\end{array}$ & 4 & 19.04 & Baccillus sp & 2 & 9.52 & \\
\hline $\begin{array}{l}\text { Cassytha filiformis } \\
\text { parasitizing on }\end{array}$ & $\begin{array}{l}\text { Lactococcus } \\
\quad \text { lactis }\end{array}$ & 4 & 13.3 & $\begin{array}{l}\text { Spirillospora } \\
\text { albida }\end{array}$ & 2 & 6.66 & 0.0 \\
\hline \multirow[t]{2}{*}{$\begin{array}{l}\text { Bougainvillea } \\
\text { spectabilis }\end{array}$} & Pantoea sp & 3 & 10 & $\begin{array}{l}\text { Curtobacterium } \\
\text { albidum }\end{array}$ & 4 & 13.3 & \\
\hline & Fungal species & $\begin{array}{c}\text { Colony } \\
\text { Frequency }\end{array}$ & $\begin{array}{c}\text { Colony } \\
\%\end{array}$ & Fungal species & $\begin{array}{l}\text { Colony } \\
\text { Frequency }\end{array}$ & $\begin{array}{c}\text { Colony } \\
\%\end{array}$ & QS \\
\hline $\begin{array}{c}\text { Cassytha filiformis } \\
\text { parasitizing on }\end{array}$ & $\begin{array}{l}\text { Asperigllus } \\
\text { niger }\end{array}$ & 1 & 25 & & 0 & 0 & 0.0 \\
\hline \multirow[t]{2}{*}{ Citrus aurantifolia } & $\begin{array}{l}\text { Aspergillus } \\
\text { reperi }\end{array}$ & 1 & 25 & & 0 & 0 & \\
\hline & $\begin{array}{l}\text { Fusarium } \\
\text { solani }\end{array}$ & 1 & 25 & & 0 & 0 & \\
\hline $\begin{array}{c}\text { Cassytha filiformis } \\
\text { parasitizing on } \\
\text { Bougainvillea } \\
\text { spectabilis }\end{array}$ & $\begin{array}{l}\text { Aspergillus } \\
\text { aculeatus }\end{array}$ & 10 & 100 & & 0 & 0 & 0.0 \\
\hline
\end{tabular}


Beatie and Lindow (1999) used the term "phyllobacteria" to refer to all the leaf associated bacteria regardless of their location and also illustrated the complexity in the ecology of phyllobacteria when they researched beyond survival strategies to a broader perspective of leaf colonization. They suggested that phyllobacteria employed a number of strategies for colonization that included, modification of the leaf habitat, aggregation, ingression, and egression. In describing these strategies, they found strong evidence in recent literature for a densitydependent interaction among bacterial cells (Swift et al. 1994, Beck-VonBodman and Farrand 1995, Greenberg 1997, Pierson et al. 1998). Such density-dependent interactions and the ability of bacteria to sense the presence of neighboring cells are often made possible by quorum sensing (QS) which is mediated by the secretion of signal molecules that belong to $\mathrm{N}$-acyl homoserine lactones (HSL) (Swift et al. 1994, Greenberg 1997).

Several types of epiphytic bacteria that have associated themselves with the foliar and root surfaces of plants, are dependent on food material shed by the plant as by-products of growth and development. This is evident by results from studies of their metabolic profile (Yadav et al. 2008). They may prefer certain types of plants and certain plant parts (Yadav et al. 2004, 2005). On foliar surfaces many of these epiphytes are rodshaped, Gram-negative, pigmented, and fermentative (Thomas and McQuillen 1952, Graham and Hodkiss 1967, Papavassiliou et al. 1967, Leben et al. 1968). Generally, most epiphytic bacteria do not harm the plant on which they reside, but in some cases, they can either be beneficial or detrimental. Certain strains of Pseudomonas syringae and Erwinia herbicola also show ice-nucleating traits, and $P$. syringae is also known to be pathogenic. Indeed $P$. syringae seems to remain as resident among epiphytic populations on grasses and trees (Malvick and Moore 1988). Xanthomonas isolates also have been found to be active in ice-nucleation (Goto et al. 1988). Besides ice-nucleation potential, certain pathogenic Pseudomonas species seem to associate epiphytically on their respective host plants. Examination of olive and oleander showed that these plants often harbor the olive knot pathogen Pseudomonas syringae pathovar savastanoi and other pseudomonads, which represent about 33 percent of the population. Other members of the epiphytic community include Bacillus (22 percent) and Xanthomonas (10 percent), as well as lesser numbers of Acinetobacter, Erwinia, Serratia, Lactobacillus, Corynebacterium and Flavobacterium, and unidentified nitrogen fixers (Lavermicocca et al. 1987). A similar list of bacteria was compiled for olive leaves, with Pseudomonas syringae pathovar savastanoi and Erwinia herbicola being the major epiphytic organisms present (Ercolani 1978). Such close association of the pathogen in the epiphytic state may be important for its long term survival. In the present study, diversity in epiphytic and endophytic bacteria depicted the host and habitat specificity. But in other study by Petrini et al. (1992), the endophyte assemblages of fir tree and its mistletoe parasite overlapped by less than $15 \%$.

Colonization ecology of phylloplane and/or phyllosphere fungi principally relates to the prevailing microenvironmental conditions on the leaf surfaces and their physical, chemical and phenological properties which affect the fungal establishment thereon (Pandey 1990, Dix and Webster 1995). The nature and abundance of epiphytic and endophytic leaf fungi have been studied mainly in forests, but their investigation with reference to host parasite are less explored (Heredia 1993, Hata et al. 2002). Result showed that microflora exhibited high degree of host specificity. Studies also supported the evidence for host preference within the endophyte and epiphyte 
community (Arnold et al. 2000). More detailed analyses of the seasonal and leaf age-dependent changes in leaf environmental conditions might provide further insights into the dynamics of endophytic and epiphytic phyllosphere microflora on $C$. filiformis and its host plants.

\section{REFERENCES}

Andrews, J.H., C.M. Kenerley and E.V. Nordheim. 1980. Microb. Ecol. 6:71-84.

Arnold, A.E., Z. Maynard, G.S. Gilbert, P.D. Coley and T.A. Kursar. 2000. Are tropical fungal endophytes hyperdiverse? Ecol. Lett. 3:267-274.

Arnold, E.A., L.C. Mejia, D. Kyllo, E. Rojas, Z. Maynard, N. Robbins and E.A. Herre. 2003. Fungal endophytes limit pathogen damage in a tropical tree. Proc. Nat. Acad. Sci. USA, 100:15649-15654.

Beattie, G.A. and S.E. Lindow. 1995. The secret life of foliar bacterial pathogens on leaves. Annu. Rev. Phytopathol. 33:145-172.

Beck-VonBodman, S. and S.K. Farrand. 1995. Capsular polysaccharide biosynthesis and pathogenicity in Erwinia stewartii require induction by an $\mathrm{N}$-acyl homoserine lactone autoinducer. J. Bacteriol. 177:5000-5008.

Brown, K.B., K.D. Hyde and D.J. Guest. 1998. Preliminary studies on endophytic fungal communities of Musa acuminata species complex in Hong Kong and Australia. Fungal Diversity 1:27-51.

Dix, N.J. and J. Webster. 1995. Fungal Ecology. Chapman and Hall, London, U.K.

Domsch , K.H., W. Gams and T.H. Anderson. 1980. Compendium of Soil Fungi. Volume I. Eching: IHW-Verlag. $860 \mathrm{p}$.

Ellis, M.B. 1971. Dematiaceous Hyphomycetes. CAB International, Oxon. 608 p.
Ellis, M.B. 1976. More Dematiaceous Hyphomycetes. CAB International, Oxon. 507 p.

Ercolani, G.L. 1978. Pseudomonas savastanoi and other bacteria colonizing the surface of olive leaves in the field. J. Gen. Microbiol. 109:245257.

Goto, M., B.L. Huang, T. Makno, T. Goto and T. Inaba. 1988. A taxonomic study on ice nulceationactive bacteria isolated from gemmisphere of tea (Thea sinensis L.), phyllosphere of vegetables and flowers of Magnolia denudata Desr. Ann. Phytopathol. Soc. Japan, 54:189-197.

Graham, D.C. and W. Hodgkiss. 1967. Identity of gram negative, yellow pigmented, fermentative bacteria isolated from plants and animals. $J$. Appl. Bacteriol. 30:175-189.

Greenberg, E.P. 1997. Quorum sensing in gramnegative bacteria. Am. Soc. Microbiol News 63:371-377.

Hata, K., R. Atari and K. Sone. 2002. Isolation of endophytic fungi from leaves of Pasania edulis of endophytic and their within-leaf distributions. Mycoscience 43: 369-373.

Heredia, G. 1993. Mycoflora associated with green leaves and leaf litter of Quercus germana, $Q$. sartorii and Liquidambar styraciflua in a Mexican cloud forest. Cryptogamie Mycol. 14:171-183.

Hirano, S.S. and C.D. Upper. 2000. Bacteria in the leaf ecosystem with emphasis on Pseudomonas syringae - a pathogen, ice nucleus and epiphyte. Microbiol. Mol. Biol. Rev. 64:624653.

Holt, J., N. Krieg, P. Sneath, J. Staley and S. Williams. 1994. Bergey's Manual of Determinative Bacteriology (9 ed.), Williams and Wilkins, Baltimore, USA. 
Inacio, J., P. Pereira, M. de Carvalho, A. Fonseca, M.T. Amaral-Collaco and I. Spencer Martins. 2002. Estimation and diversity of phylloplane mycobiota on selected plants in a mediterranean-type ecosystem in Portugal. Microb. Ecol. 44:344-353.

Lavermicocca, P., G. Surico, L. Varvaro and N.M. Babelegoto. 1987. Plant hormone, cryogenic and antimicrobial activities of epiphytic bacteria of live and oleander. Phytopathol. Mediterr. 26:65-72.

Leben, C., G.C. Daft and A.F. Schmitthenner. 1968. Bacterial blight of soybeans: population levels of Pseudomonas glycinea in relation to symptom development. Phytopathol. 58:11431146.

Lindow, S.E. and M.T. Brandl. 2003. Microbiology of the phyllosphere. Appl. Environ. Microbiol. 69:1875-1883.

Malvick, D.K. and L.W. Moore. 1988. Population dynamics and diversity of Pseudomonas syringae on apple and pear trees and associated grasses. Phytopathol. 78:1366-1370.

Morris, C.E. and L.L. Kinkel. 2002. Fifty years of phyllosphere microbiology: significant contributions to research in related fields. In: Phyllosphere Microbiology. (eds.) Lindow, S.E., E.I. Hecht-Poinar and V.J. Elliott. APS Press, St Paul, USA, pp. 365-375.

O'Brien, R.D. and S.E. Lindow. 1989. Effect of plant species and environmental conditions on epiphytic population sizes of Pseudomonas syringae and other bacteria. Phytopathology 79:619-627.

Osono, T. and A. Mori. 2004. Distribution of phyllosphere fungi within the canopy of giant dogwood. Mycoscience 45:161-168.

Osono, T. and A. Mori. 2005. Seasonal and leaf age-dependent changes in occurrence of phyllosphere fungi in giant dogwood. Mycoscience 46:273-279.

Pandey, R.R. 1990. Succession of microfungi on leaves of Psidium guajava L. Bull. Torrey. Bot. Club 117:153-162.

Papavassiliou, J., S. Tzannetis, H. Leka, and G. Michopoulos. 1967. Coli-aerogenes bacteria on plants. J. Appl. Bacteriol. 30:219-223.

Petrini, O., T.N. Sieber, L. Toti and O. Viret. 1992. Ecology, metabolite production, and substrate utilization in endophytic fungi. Natural Toxins I: 185-196.

Pierson, L.S., D.W. Wood, E.A. Pierson and S.T. Chancey. $1998 . \quad \mathrm{N}$-acyl-homoserine lactonemediated gene regulation in biological control by fluorescent pseudomonads: current knowledge and future work. Eur. J. Plant Pathol. 104:1-9.

Rasche, F., R. Trondl, C. Naglreiter, T.G. Reichenauer and A. Sessitsch. 2006. Chilling and cultivar type affect the diversity of bacterial endophytes colonizing sweet pepper (Capsicum anuum L.). Can. J. Microbiol. 52:1036-1045.

Rodrigues, K. 1994. The foliar fungal endophytes of the Amazonian palm Euterpe oleracea. Mycologia 86:376-385.

Schweitzer, J.A., R.K. BaileyBangert, S.C. Hart and T.G. Whitham. 2006. The role of plant genetics in determining above- and belowground microbial communities. In: Microbial Ecology of the Aerial Plant Surface. (eds.) Bailey, M.J., A.K. Lilley, A.K., P.T.N. TimmsWilson and P.T.N. Spencer-Phillips. CABI International, Wallingford, UK, pp. 107-119.

Smibert, R.M. and N.R. Krieg. 1981. General characterization. In: Manual of Methods for General Bacteriology. (eds.) Gerhard, P., R.G.E. Murray, R.N. Costillow, E.W. Nester, 
W.A. Wood, N.R. Krieg and G.B. Phillips. American Society for Microbiology, Washington, D.C., pp. 409-443.

Southcott, K.A. and A. Johnson. 1997. Isolation of endophytes from two species of palm from Bermuda. C. J. Microbiol. 43:789-792.

Stapleton, A.E. and S.J. Simmons. 2006. Plant control of phyllosphere diversity: genotype interactions with ultraviolet- B radiation. In: Microbial Ecology of the Aerial Plant Surface. (eds.) Bailey, M.J., A.K. Lilley, P.T.N. TimmsWilson and P.T.N. Spencer-Phillips. CABI International, Wallingford, UK, pp. 223-238.

Suryanarayanan, T.S., V. Kumaresan and A. Johnson. 1998. Foliar fungal endopytes from two species of the mangrove Rhizophora. C. J. Microbiol. 44:1003-1006.

Swift, S., N.J. Bainton and M.K. Wilson. 1994. Gram-negative bacterial communication by $\mathrm{N}$ acyl homoserine lactones: a universal language? Trends in Microbiol. 2:193-198.

Thomas, S. and J. McQuillin. 1952. Coliaerogenes bacteria isolated from grass. Proc. Soc. Appl. Bacteriol. 15:41-52.

Thompson, I.P., M.J. Bailey, T.R. FenlonFermor, A.K. Lilley, J.M. Lynch, P.J., McCormack and
M.P. McQuilken. 1993. Quantitative and qualitative seasonal changes in the microbial community from the phyllosphere of sugar beet (Beta vulgaris). Plant Soil 150:177-191.

Wilson, M. and S.E. Lindow. 1994. Inoculum density-dependent mortality and colonization of the phyllosphere by Pseudomonas syringae. Appl. Environ. Microbiol. 60:2232-2237.

Yadav, R.K.P., E.M. Papatheodorou, K. Karamanoli, H.A. Constantinidou and D. Vokou. 2008. Abundance and diversity of the phyllosphere bacterial communities of mediterranean perennial plants that differ in leaf chemistry. Chemoecology 18:217-226.

Yadav, R.K.P., J.M. Halley, K. Karamanoli, H.A. Constantinidou and D. Vokou. 2004. Bacterial populations on the leaves of mediterranean plants: quantitative features and testing of distribution models. Environ. Exp. Bot. 52:6377.

Yadav, R.K.P., K. Karamanoli and D. Vokou. 2005. Bacterial colonization of the phyllosphere of mediterranean perennial species as influenced by leaf structural and chemical features. Microb. Ecol. 50:185-196. 